\title{
Friends, Enemies, Writers: Dos Passos and Hemingway
}

\section{Clara Juncker}

University of Southern Denmark

\begin{abstract}
John Dos Passos and Ernest Hemingway both embodied the post-WWI world of loss, disillusion, and modernist experimentation. Critics have mostly discussed the two prominent members of the Lost Generation in terms of their different writing techniques and interests, not to mention their different approaches to politics, life choices, and what Hemingway called "things of the night." Nonetheless, the two writers had much in common: their war experiences, their appetites for travel and adventure, and their ambitions as writers. Though the two friends had significantly different personalities and physiques, they used each others as mirrors, in which they scrutinized, admired, or grimaced at their own abilities and flaws as men and writers. After their famous 1937 break-up in Spain, where they disagreed, quarrelled and ultimately split up over Spanish politics, which neither of them understood, they saw each other as enemies, or monsters. They both lost something other than the friendship of their youth. Dos Passos lost the innocent exuberance the young American writers had found in Europe. He also lost his masculinity, his literary mentor, and his global travelling companion. He said farewell to Europe, his radical visions, and his best writing. Hemingway lost empathy and generosity, and his protection against excess and despair. He lost his sparkle. As members of the Lost Generation, Dos Passos and Hemingway had both survived their post-WWI existence through writing and comraderie, but now each man faced the universal catastrophe, and the decades of struggle with words they mastered and demons they did not, alone.
\end{abstract}

Keywords: John Dos Passos-Ernest Hemingway-autobiography-World War I the Lost Generation-American literature-writing-Key West-the Spanish Civil War-friendship 
John Dos Passos published The Best Times: An Informal Memoir (1968) about three decades after his estrangement from Hemingway. True to his title, Dos Passos includes in this slim autobiography the high points of the two writers' long relationship. In "La Vie Littéraire," he remembers Paris from 1924 onwards, when Hem and Hadley lived on rue Notre Dame des Champs, after their son Bumby's arrival. In "Under the Tropic," he recalls good times with Hem and Pauline, the second Mrs. Hemingway, in Key West, especially in late April and early May of 1929, when a frazzled Dos Passos arrived from a stint at the New Playwrights Theater in New York (BT 197). But bitterness and disappointment lurk behind Dos Passos's resolutely cheerful memoirs, which cover up the personal and political differences that later separated "Dos" and "Hem." The two had different personalities: Dos Passos was withdrawn and unathletic, hardly a match for Hemingway - known, of course, for his athletic prowess and bluster. The personalities of the two men overlapped, however, in ways largely unexplored by critics and biographers. They shared more than their writer's profession and the search for a prose style suited to their purposes; in fact, they saw each other as mirror images. But after they quarrelled over Spanish politics in 1937, they saw each other as monsters, the autobiographical other hiding behind the mirror. As enemies, they both lost out. Dos Passos lost the innocence and the ideals the young writers had shared in Europe. He also lost a manly, convivial part of himself, and his mentor and fellow traveller. He lost Europe. He lost his radical dreams and his best prose. Hemingway lost generosity and kindness, as well as his bulwark against excess and despair. He lost, for a while, his luster. As prominent members of the Lost Generation, they both used their work to cope with the post-WWI world, but now each man faced the universal catastrophe alone. Dos Passos sums up his feelings about Hemingway in a postcard to Sara Murphy, a mutual friend from their youth: "Until I read of his poor death I didn't realize how fond I'd been of the old Monster of Mt. Kisco" (Ludington, $14^{\text {th }}$ Chronicle, 623). His response to old Hem remains complex, but some affection survived the decades in which they both struggled with words, with life, and with the demons they never overcame.

The two writers became close in 1924 during Dos Passos's "fitful stopovers in Paris," when they would meet for vermouth cassis at the Closerie des Lilas and discuss what they read, wrote, and did not write. On many late afternoons they strolled back to help Hadley give Bumby his bath, awaited the arrival of the French babysitter, and then all three went out for dinner. 
Dos Passos and Hemingway remembered each other "dimly" from Schio in May, 1918, when Dos Passos was preparing to leave Section 1 of the Red Cross Ambulance Service and Hemingway had just arrived with Section 4. Based in Bassano, Dos Passos evacuated wounded soldiers to a base hospital near Schio and on one of these trips must have "messed" with Section 4 (BT 141). Biographer Townsend Ludington writes that Dos Passos and his friend, Sydney Fairbanks, would eat with Section 4 at the hospital. He is not sure that Dos Passos and Hemingway met here, but both writers and Fairbanks remember the occasion, though their recording of dates is imprecise. Fairbanks felt left out, because Dos Passos and Hemingway immediately took to one another. He remembers as well that Hemingway was already impressive, and opinionated (Ludington, Odyssey, 159).

In Paris, Dos Passos and Hemingway both belonged to the circle around Ford Madox Ford's The Transatlantic Review, which Hemingway edited in Ford's absence. In the fall of 1924, Dos Passos brought the In Our Time manuscript to publishers in New York City, where he and Sherwood Anderson successfully pushed Hemingway's first book into print. Dos Passos wrote a blurb for the dustjacket, though Hemingway did not like the cover (Reynolds 205, 208, 232, 235). Dos Passos would ski with Hemingway and Hadley in Schruns, Austria, go with their circle to Pamplona the year before the Sun crowd, and fish and drink with Hemingway in Key West. In Florida Dos Passos met Katy Smith, who had grown up with Hemingway, been a friend of Hadley's, and known Pauline and Jinny Pfeiffer, now Hemingway's wife and sister-in-law, at the University of Missouri. "They were all very thick," Dos Passos writes in The Best Times of Hemingway, Pauline, their friends, and especially Katy. "From the first moment I couldn't think of anything but her green eyes" (BT 200). Dos and Katy were married in August, 1929, and the couple frequently returned to Key West. After Dos Passos had been hospitalized in New York with rheumatic fever, they rented a house in Key West for the spring of 1934, and Dos Passos joined Hemingway in Havana for the May Day celebrations. Both writers travelled back to France and Spain, hunted in Montana, and fished and swam in Florida.

In 1937 they both travelled to Europe to shoot The Spanish Earth, a documentary they hoped would cause President Roosevelt to repeal his arms embargo against Spain. It was here that the irreparable break between the two writers occurred, ostensibly caused by different takes on the fate of Dos Passos's friend José Robles. In Valencia, Dos Passos had visited the apartment of his old friend, but found only his haggard wife, who told him 
that Robles had been arrested. A non-Communist leftist with no Fascist leanings, as both Dos Passos and Edmund Wilson saw him, Robles might have been indiscreet in discussing information gained in the fall of 1936, when he translated for the Russian General Goriev, stationed in Madrid. Robles had also interviewed his brother in prison and pressed him to join the Loyalists. Dos Passos came to fear that his friend stood in the way for a Russian take-over of the Republic. He asked Spanish officials in Valencia about Robles and continued his inquiries, though Liston Oak, an American working for the Republican Press Bureau in Valencia, had told "Coco," Robles's son, that his father was dead. If Robles had indeed been killed, Dos Passos concluded from the information he received, along with U.S. Embassy officials, that Robles had been taken away and shot by anarchist "uncontrollables" (Ludington, Odyssey, 367; Carr 366-77).

Back in Madrid, Dos Passos joined Hemingway and Martha Gellhorn at the Hotel Florida, regularly under bombardment. Hemingway blamed Dos Passos for not bringing food to Madrid, where rations were scarce, at least for outsiders. He cared little for Robles and for Dos Passos's distress and more for his own adventure, the bombs, the danger, his blond mistress. And when he heard from journalist-writer Josephine Herbst in the Hotel Florida lobby that Robles was dead for sure, he did not tell his friend right away. He told him at a fiesta in honor of the Soviet-Spanish Fifteenth International Brigade in the foothills of the Guadarramas, where foreign correspondents were invited to lunch and parades. The account is hazy. Was Hemingway first to break the news quite casually, or did Dos Passos know already? Was he angry at his friend mostly for his delay, his cruel insensitivity? Did Hemingway tell him to shut up so as not to jeopardize their Spanish Earth project? And that Robles had been guilty of treason and shot as deserved? (Ludington, Odyssey, 368-73). Both writers would confront or tiptoe around this conflict in the publications that followed: journal articles, letters, novels, autobiographies. Their narratives clash, perhaps because of the nature of storied lives. As writers and storytellers, they inhabited fictional identities created from underlying needs and desires. Each of the two would shape a slippery self within a slippery genre, the made-up identities of fictional autobiography or autobiographical fiction. As theorists of autobiography remind us, the unreliable narrators tell us not the truth, but the story-truth that may be truer to their experiences in the first place (Eakin). Dos Passos and Hemingway lived this truth - and wrote about it - differently. 
Stephen Koch argues in The Breaking Point: Hemingway, Dos Passos, and the Murder of José Robles (2005) that by 1937 Spain had become a morass of political intrigues, infiltrations, and assassinations. Neither Dos Passos nor Hemingway understood the situations and the silences they met, but they did not react alike. Dos Passos held that Communists had murdered Robles, while Hemingway believed that Robles had been a Fascist spy, a theory circulated among American Communist sympathizers and maybe originating in Stalinist propaganda. Josephine Herbst sums up their differences. "It should be remembered," she writes in 1939 to Bruce Bliven of the New Republic, "that Dos hated war of all kinds and suffered in Madrid not only from the fate of his friend but from the attitude of certain people on the fringe of war who appeared to take it as a sport. A deep revulsion followed" (Ludington, Odyssey, 372).

Dos Passos left Spain and Europe behind. Hemingway appeared at the boat train depot in Paris to see Dos Passos and Katy off. Heated words, a Dos Passos shrug, and a raised Hemingway fist presumably marked the end of the friendship (Ludington, Odyssey, 374; Carr, 372). Each of the two would later sling invective at the other, though Hemingway remained the least discreet. In articles for Ken magazine, including "Treachery in Aragón," Hemingway scoffed at a balding American writer who arrived in Valencia in 1937 and right away tried to make "liars out of every honest correspondent in Madrid" by charging the Republican government with hunting down and shooting thousands of Loyalists, without himself leaving his hotel room (Carr 376-77). In To Have and Have Not (1937), Hemingway identifies with Harry Morgan, the independent Key West fisherman driven to crime, while Richard Gordon, an enervating radical writer, resembled Dos Passos so much that publisher Arnold Gingrich warned Hemingway about a possible libel suit. Dan Shen would position Gingrich in the "uncognizant audience," made up of readers blind to the gap between the text and the personal experience it represents (48). The publisher, of course, would have to deal with lawyers equally unaware of genre fictionality.

Donald Pizer, Scott Donaldson, 'lownsend Ludington and Stephen Koch have differently explained the Dos Passos-Hemingway quarrel: with jealousy, with politics, with territorial feelings about Spain, and with different interpretations of Spanish rituals (Ludington, "Spain"). But critics agree on the personality differences that defined and (un)balanced the relationship. Despite the young Dos Passos's many acquaintances among the Bohemians of Greenwich Village and the American expatriates in Europe, he was 
shy and reserved. In I Thought of Daisy (1929), Edmund Wilson describes Dos Passos, alias Hugo Bamman, as a huge, awkward fellow, who would blunder into rooms "in his purblind bigbooted way," "staring out through his thick myopic lenses" and speaking in stutters, bubbles and giggles. He would always leave his hat within easy reach at parties, ready for quick departures (101). In contrast, Carlos Baker comments on Hemingway's "capacity for friendship" and sees in his letters "his longing to gather his closest male friends around him for hunting, fishing, drinking, or conversational exploits. The formula varied little from his nineteenth to his fiftyninth year" (Letters xviii). When Martha Gellhorn arrived in New York in 1936 because Hemingway had "begged" her to, the city and Hemingway did not meet her expectations. Instead of "long flirtatious meetings, time to talk seductively about writing and political commitments," they were "always in a crowd," with people rushing in and out, phones ringing, and everybody drinking at the Stork Club and Twenty One (Moorehead 107). Dos Passos recalls that "Hem always did have a gang of people with him" (BT 199).

Dos Passos was modest, bashful, given to self-irony-hardly characteristic Hemingway traits. Across from the title page of The Best Times, Dos Passos recounts an incident at Moskowitz's, in the Lower East Side, New York, during Prohibition days: An "intenselooking" high school senior seats himself across from Dos Passos and asks him why he doesn't act like a writer. Dos Passos answers that even if he did know how a writer ought to act, "How do you know I'd want to act like a writer?" The young man glares at him, gets up, and gropes for words. "'Let me tell you one thing,' he spluttered all out of breath, 'meeting you sure is a disappointment"' $(B T$, n.p.). The Dos Passos of the autobiography is far from disappointing, but his modesty prevails. He stays clear of Hemingway's boxing: "Having my glasses as an excuse I had no need to compete with him in that department." Dos Passos continues: "I couldn't ride a bicycle either" (BT 142). Nor could he ski. With Hemingway and Hadley in Schruns, "Hem went in for skiing up to the hilt. He practiced and practiced," Dos Passos writes. "He had to be tops." Dos Passos had a better time than the others, for one good reason: "I knew from the first I'd never be any good. Too damn clumsy" ( $B T$ 159). Nor could he shoot, or tell one bicycle rider at the six-day races from another, though he dutifully went along. Hemingway, he explains, "had an evangelistic streak that made him work to convert his friends to whatever mania he was encouraging at the time." Hemingway knew all the statistics 
and all riders' names and lives. "His enthusiasm was catching," Dos Passos remembers, "but he tended to make a business of it while I just liked to eat and drink and to enjoy the show" (BT 143).

Early on, Hemingway could take a joke, but things got more "rocky," maybe because of the "literary gaspers" (BT 142). In Key West, Katy and Dos Passos met "the famous author, the great sportsfisherman, the mighty African hunter," but they tried "to keep him kidded down to size." "We played up to him some at that," Dos Passos adds, particularly when Hemingway would go to bed before supper: "we'd all bring him drinks and eat our supper on trays around the bedroom. We called it the lit royale" (BT 219). In a February 1932 letter, written after four days in Key West, Dos Passos objects to certain passages in Death in the Afternoon "where Old Hem straps on the longwhite whiskers and gives the boys the lowdown" (Ludington, $14^{\text {th }}$ Chronicle, 402). In a letter to Hemingway from Mexico one month later, Dos Passos again tries the humoristic approach: "Hope the big social life died down and Mahatma settled down to quiet contemplation among his books and papers" (Ludington, $14^{\text {th }}$ Chronicle, 406).

Dos Passos writes in The Best Times that "Hem was hard on his women" (BT 143). Dos Passos himself was scared of them. Edmund Wilson writes in I Thought of Daisy:

He was rather afraid of women, and seemed never to fall in love. . . . So he would flee from even parties in the Village, when any situation arose which seemed to suggest a love affair, and go home to write with passion, almost with amorous feeling, of some girl bandit who had been harshly sentenced and brutally denounced by a stupid judge

- of whom he had read in the evening paper. (100)

During a famous lunch in 1922, the Fitzgeralds called Dos Passos "backward" and "inhibited about sex," but he fended them off (BT 128). Dos Passos would in these years tell friends that he was visiting a "Little Lady in Green" up the Hudson, when in reality his visits to four Chicago women, the Dudley sisters and Susan Smith, were "discreet and chaste," rooted in a shared enjoyment of nineteenth-century refinement (Ludington, Odyssey, 220). Dos Passos's engagement to Chrystal Ross remained platonic. The two had met in August 1922, but in Pamplona with Hemingway and his circle in 1924, Dos Passos and Chrystal had maintained separate rooms. Dos Passos was eager to get married, but Chrystal held back and decided to end their long engagement in 1926. After the break, Dos Passos confessed to his friend Rumsey Marvin that he did not understand why people got 
engaged. But, he concluded, "my private life is such a disorganized menagerie of illfed desires that I'm no authority on Hymen ...." (14 Chronicle 364). Hemingway's life was no less chaotic in 1926, but at least he knew about women. Dos Passos felt "convinced that he was more of a builderupper than a breakerdowner. He left them more able to cope with life than he found them" (BT 143).

Writers and writing cemented the friendship between Dos Passos and Hemingway, but they approached their craft differently: "Literary invention could never be made really reputable," Dos Passos believed. "A writer who took his trade seriously would be sure to get more kicks than ha'pence. He would be lucky if he stayed out of jail." Though he never discussed such things even with intimate friends, he had sworn allegiance to "an imaginary humanist republic" that to him represented "the struggle for life against the backdrag of death and stagnation" (BT 134). Because of his secret oath, he professed to take no interest in the number of copies his books sold. Dos Passos's departures were particularly sudden upon the publication of a new book, when he "bolted for foreign parts" (BT 132). "The celebrity racket," he writes in The Best Times, "made no sense at all" (134). Sure enough, Dos Passos was eternally broke and would repeatedly borrow from friends - Hemingway a prominent benefactor among them.

The generosity and complexity of the friendship between Dos Passos and Hemingway originated as well in overlapping interests and character traits. They moved in the same circle of friends and acquaintances: Archibald and Ada MacLeish, F. Scott and Zelda Fitzgerald, Sara and Gerald Murphy and the expatriates at the Villa America (BT 153). Both men loved to drink, and Dos Passos enjoyed the many hunting and fishing trips he took with Hemingway. Both men were in the Ford roadster that went into the ditch near Billings, Montana. Dos Passos writes: "Everybody blamed me with my bad eyesight but I swear Hemingway was at the wheel. Of course we had been drinking right much bourbon" (BT 205). Both men were indeed accident-prone. In 1947, Dos Passos would tragically lose Katy Smith in a car crash, himself at the wheel. As for Hemingway, Dos Passos claims never to have known "a man who did so much damage to his own carcass" ( $B T$ 142). Dos Passos was sick a lot, with malaria, or with rheumatic fever especially, and Hemingway also spent much time in bed. Dos Passos writes: "When it wasn't an accident it was a sore throat. He was like one of those professional athletes who, although strong as an ox, is always nursing some ailment" (BT 142). In moments of real crisis, Dos Passos proved himself as 
courageous as Hemingway. During World War I, Dos Passos and his friends "had been under fire enough to discover that we weren't any more scared than the next man. We were still tingling with that great moment of a man's life when he finds that he can take fright and danger and somehow shrug it off" (BT 43). Throughout his travels, his controversies, and his tragedies, Dos Passos proved himself to be a Hemingway hero of sorts.

Even with women, Dos Passos located some courage. The young author of several war novels had found out that the ladies were not uninterested, and certain pleasures make it into The Best Times. Dos Passos stopped wearing glasses and gained exotic, even erotic appeal. Edmund Wilson barely recognized the changed "Hugo" in I Thought of Daisy: "Hugo had now unsheathed from behind his mild round blinders a darkly burning and eagle-like glance, beneath a steep and sharp-jutting brow. . . Without the glasses, he seemed to have become a more interesting person and a person with whom it was easier to communicate. . (172). A William Spratling sketch of Dos Passos from New Orleans days in the spring of 1924, when he had gone South to work on Manhattan Transfer, confirms Wilson's impression. Dos Passos's dark eyes sparkle with intelligence, curiosity, and a touch of devilishness. No longer blind to female charm, Dos Passos writes to Rumsey Marvin from New Orleans: "P. S. You never saw such good looking girls as this city produces" (Ludington, 14th Chronicle, 358).

Each writer found Spain equally stimulating. "One of the things that had brought Hem and me together was our enthusiasm for things Spanish," Dos Passos writes in The Best Times (154). After graduating from Harvard in 1916, Dos Passos had lived and written in Spain into early 1917, and again from August 1919 to April 1920. His first Spanish essays, Rosinante to the Road Again, appeared in 1922. Townsend Ludington writes in "Spain and the Hemingway-Dos Passos Relationship" (1988): "All this was before Hemingway's first trip to Pamplona in 1923" (271). The two friends went to bullfights, and both tried in 1934 to help the Spanish artist Luis Quintanilla, jailed in Madrid for his activities in the October Revolution and eventually released. And then there was The Spanish Earth, the documentary they were to have made together. Before the break, the two recognized each other's intimacy with Spain. Apart from admiring Death in the Afternoon, Dos Passos complimented Hemingway for an Esquire story: "You certainly have Madrid down cold-It made me feel as if I was there and just about to go down to the Cafe du Puerto Rico to have coffee and read the papers in the morning" (Ludington, 14 ${ }^{\text {th }}$ Chronicle, 484). In 1931, Hemingway had 
written to Dos Passos from Madrid: "You are the great writer of Spain" (Baker, Letters, 342).

From their Paris days onwards, Dos Passos and Hemingway mirror each other in their commitment to writing and reading: "We talked about the difficulties of putting things down on paper. We were both reading the Old Testament. We read to each other choice passages. The song of Deborah and Chronicles and Kings were our favorites" (BT 141-42). Dos Passos believed that "basing his wiry short sentences on cablese and the King James Bible, Hem would become the first great American stylist" (BT 142). He "trumpeted" In Our Time to Horace Liveright, the publisher, and earned a letter of thanks from Hemingway (BT 142). He tried to stop his friend from publishing The Torrents of Spring (1925), a parody of Sherwood Anderson's Dark Laughter (1924), and omitted direct references to Hemingway's second book in a chatty letter about writing and publishing he sent from New York in March 1927 (Ludington, $14^{\text {th }}$ Chronicle, 368).

Hemingway would pay back Dos Passos in kind. In Key West, he introduced his friend to Arnold Gingrich, who was just starting Esquire magazine, and apparently, he played the editor as well as he played a marlin. Hemingway knew about "high literary finance" and managed to sell Gingrich his passion for fishing as well as a couple of Dos Passos pieces (BT 216). On board a ship to Europe in 1933, Dos Passos thanked his pal: "Your buddies may come in very handy, Captain Hemingway" (Ludington, $14^{\text {th }}$ Chronicle, 432). Hemingway also gave plenty of advice to his fellow writer. In a letter from Key West in 1932 that Baker labels Hemingways's quid pro quo for Dos Passos's comments on Death in the Afternoon in manuscript, he praises Nineteen Nineteen, but tells Dos Passos to watch out for "perfect characters" and to try not to "do good." He asks Dos Passos not to "coast along" in the narrative sections. In a subsequent letter he is careful again: "You don't need any advice" (Baker, Letters, 354, 356).

Both listencd to the other, sometimes willingly and sometimes reluctantly. In 1932, Dos Passos writes from Provincetown: "Havent got the letter and lit. advice (Jeez we're getting to heave lit. advice back and forth like regular wordfellows, but it can't be helped, once you're in the business) but damned anxious to read some and hope it will be sent back intact by Am. Express in Mexico City" (Ludington, $14^{\text {th }}$ Chronicle, 407). In 1936, he writes to Hemingway how hard it is to make a living out of writing books, and how hard it is to read one: "I read and read and if I keep up I ought to be able to get a college degree-God damn it, to try to use your mind is 
difficult painful \& hazardous - no wonder so few people do it" (Ludington, $14^{\text {th }}$ Chronicle, 492).

The two men bonded over writing, publishing and reading. In Key West, they shared a routine. At night they would "drink and talk and talk and talk far into the moonlit night" (BT 201). They would both rise very early, write, and then go fishing. Busy with the proofs for The $42^{\text {nd }}$ Parallel, Dos Passos asked Hemingway to pray for him in his "battle for the four-letter words" (BT 202). Both writers sought from the first to render the every-day speech of ordinary people without moral glossing. In Allentown, Pennsylvania, between his first and second WWI assignment, Dos Passos was taking notes on his army buddies' talk: "A farm boy from Indiana and a little wop from somewhere out west gave me the first intimations of the characters in Three Soldiers" (BT 73). In 1925, Hemingway writes to Scott Fitzgerald that "Dos, fortunately, went to the war twice and grew up in between. His first book was lousy" (Baker, Letters, 177). In the period between this letter and their 1937 quarrel, his friend's accomplishments receive mostly praise: "Dos Passos is often an excellent writer and has been improving in every way with each book he writes" (Baker, Letters, 366). Hemingway defended Dos Passos's works to others, among them the editors of Hound and Horn, who had accepted a review that trashed the writings of Fitzgerald, Dos Passos, and Hemingway himself (Baker, Letters, 368).

Dos Passos and Hemingway enjoyed each other for as long as they enjoyed each other. Each reflected himself in the other. Dos Passos becomes in letters to Hemingway quite manly. He refers to fishing, hunting, skiing and sailing, and when travelling to Russia, outside of Hemingway's territory, he writes of topics the other would enjoy: food, alcohol, parties. His letters employ a masculine discourse littered with four-letter words. When he cannot impress Hemingway through actual activities, as in 1933 during a bout with rheumatism at Johns Hopkins Hospital, he acts tough: "This is a hellishly disagreeable disease, but is not chronic arthritis, in which I am damn lucky - according to the big boss medic here it always eventually leaves your carcase free. ..." (Ludington, $14^{\text {th }}$ Chronicle, 426). Dos Passos spices up his masculine lingo with references to a surplus of "drawing room bitches" and other undesirables - "it's like fairies getting into a bar-ruin it in no time" (Ludington, $14^{\text {th }}$ Chronicle, 408). Together the two are men's men, drinking in a real-guys-only environment. In mentioning to Hemingway that all his reading might lead to a college diploma, Dos Passos invents himself as a working class hero, less privileged than his Harvard degree 
would suggest. He also mirrors his correspondent, who did not go to college and was a bit touchy about it. Dos Passos repeatedly scrapes up news about their mutual acquaintances so as to prove himself a gossip worthy of his friend. Hemingway declares himself "a perfectly safe man to tell any dirt to as it goes in one ear and out my mouth" (Baker, Letters, 447).

In letters to Dos Passos, Hemingway presents himself as modest, generous, sensitive, and political. He mentions to Dos Passos that he likes to have Gertrude Stein criticize his writing, "because it keeps one['s] opinion of oneself down - way down" (Baker, Letters, 310). He credits Dos Passos with influencing his own writing: "In plain talk I learned to write from you" (310). He asks about Dos Passos's health and congratulates him on his wedding, addressing the newlyweds as "you men" (303). He constantly writes that he misses Dos Passos - his company and conversation - and tries until 1937 to take an interest in Dos Passos's political causes. "I can't be a Communist because I hate tyranny and, I suppose, government. But if you're ever one its swell with me" (360). Though the tough, manly Hemingway looms large in the correspondence, he manages to show a more nurturing side of himself. He spends much time at home in bed, he worries about Pauline and their sons, and he takes care of Dos Passos as well: with advice, with commiseration, with money, and with the many words mailed to his friend.

Overlapping geographies helped the two writers become mirror images. In Italy in WWI, they both grew up under fire and (in)action. In Paris, they moved in an erotic terrain associated with writing (Pizer, "Sexual Geography”). In Spain, they discovered Spanish culture, Spanish rituals and especially Spanish people, though none of them got the politics worked out. And in Key West, they discovered a paradise where they might reinvent themselves, and each other. As Dos Passos writes in The Best Times, "I've forgotten whether I first told Hem about Key West or whether he found it on his own." Like their friendship, it became a very special place. Dos Passos mentions the "dreamlike" crossing of the Keys and tells his readers that "in those days Key West really was an island. . . . It was like no other place in Florida" (BT 198).

When Dos Passos first visited the Hemingways in Key West in March 1929, worn out by New Playwrights schedules and bickering, the island appeared to him "like the Garden of Eden" (BT 201), with Katy Smith as a green-eyed Eve. At this idyllic time, he got along fine with his host: "Although as competitive as a race horse, Hem wasn't yet so much the profes- 
sional sportsman as to spoil the fun" (BT 202). From the Over Sea Hotel in Key West, March 1929, Dos Passos tells Edmund Wilson that he is "remaking the inner man, somewhat shattered by the encounter [with Drama]." He treats Wilson to an overview of Key West history, from its whaling days to cigar rolling industry to overseas highway boom and bust, and announces that catching and shipping green turtles is now the only industry. "It's a swell little jumping off place," Dos Passos tells Wilson, "- the one spot in America desperately unprosperous." With Hemingway and his crowd, he had located a paradise (Ludington, $14^{\text {th }}$ Chronicle, 391).

In 1934, Dos Passos and Katy spent the spring in Key West, his rheumatism still proving "a hell of a thing to shake off" (Ludington, $14^{\text {th }}$ Chronicle, 451). Hemingway and Key West seemed less appealing now, though good points remaincd. Hemingway was becoming tiresome: "We had gotten to calling Hem the Old Master because nobody could stop him from laying down the law. ... He had more crotchety moments than in the old days, but he was still a barrel of monkeys when he wanted to be" (BT 211). Key West was "quiet as a cemetery." Like Dos Passos's host, it got mixed reviews: "it's horribly dull but has some agreeable features," he writes to Robert Cantwell, friend, novelist, and editor at Time, "its fine for the halfsick and for deep sea fishing -" (Ludington, $14^{\text {th }}$ Chronicle, 452).

Dos Passos began to worry about "communist holier than thouishness" (Ludington, $14^{\text {th }}$ Chronicle, 464) about the time Hemingway began to take some interest in politics. At this point Dos Passos and Katy had just about had it with Hemingway and Key West. The Old Master fired at a shark and shot himself in the legs, in Katy's view due to his "imprudent exhibitionism" (Carr 340). In 1935, Key West was "bankrupt." "The processes of liquidation of the ordinary citizen all appear enlarged here as in a microscope," Dos Passos writes a friend. The result, he concludes, "is that what was a town of small owners and independent fishermen and bootleggers is rapidly becoming a poor farm. It's all very comic tragic and useful to me in my business if I can keep out of jail long enough to write about it" (Ludington, $14^{\text {th }}$ Chronicle, 469). Obviously, both Hemingway and Key West still managed to hold his interest.

The quarrel in 1937 was painful for both writers, in different ways. In The Best Times Dos Passos approaches the subject in the most general of terms. Though Hemingway had been dead some three or four years, Dos Passos needs a generalizing buffer between himself and Hemingway, or his own pain: 
The troubles that arise between a man and his friends are often purely and simply the result of growing up.... As a man matures he sheds possibilities with every passing year: In the same way he sheds friendships. In an age like ours when political creeds drive men to massacre and immolation, political opinions become a matter of life and death. Differences which, when men and women were still in their twenties, were the subject of cheerful and affectionate argument brew recrimination and bitterness when they reach their thirties. (BT 219)

"Old friends," Dos Passos explains without direct reference to Hemingway, "turn into unfriends or even into enemies" (BT 219). This general section on friends and enemies interrupts an account of Dos Passos's Key West adventures and points to his fall-out with Hemingway. The bull(fight) imagery and the focus on "men of letters" help get his ideas about Hemingway across:

Men of letters suffer from conceit more than ordinary men. They are an egotistic lot. Friendships between them are precarious. They are a little like bulls that way. The bull that was friendly and playful as a calf will gore the guts out of you at the drop of a hat when he's grown. (BT 219)

Hemingway mailed a vituperative letter to Dos Passos in the wake of their quarrel in Europe. Writing from Paris in March 1938, Hemingway told Dos Passos to get his facts right when he attacked those still fighting in Spain. Loyalist commanders, Hemingway explained, were not Russian Communists but came from all over to help fight the Fascists. The letter accuses Dos Passos of being "crooked," of sell-out and corruption. "So long Dos," Hemingway begins his final paragraph and then works himself into rage and self-pity:

Good old friends. Always happy with the good old friends. Got them that will knife you in the back for a dime. Regular price two for a quarter. Two for a quarter, hell. Honest Jack Passos'll knife you three times in the back for fifteen cents and sing Giovanezza free. Thanks pal. Gee that feels good. Any more old friends? Take him away, Doc he's all cut. Tell the editor's secretary to make Mr. Passos out a check for $\$ 250$. Thank you Mr. Passos that was very very neat. (Baker, Letters, 464-65)

Over time, Hemingway alienated most writers and close friends, including Martha Gellhorn, his third wife. Caroline Moorehead writes in Gellhorn: A Twentieth-Century Life (2003) that Martha would threaten to sue anyone who mentioned Hemingway's name with her own. To her mother, Martha wrote: "A man must be a very great genius to make up for being such a 
loathsome human being" (230). Hemingway got back at Martha, as readers of Across the River and into the Trees will know. Dos Passos did not approve. In a July 1950 letter to Edmund Wilson, he wrote that "Hemingway's story (the parts I read) brought out the goosepimples in a different way. How can a man in his senses leave such bullshit on the page?" The mirror function still works at mid-century, since Dos Passos finds himself reflected in Hemingway's failure: "It made me wonder whether I really did get all my bullshit into the wastebasket in time" (Ludington, $14^{\text {th }}$ Chronicle, 591).

With the break-up, Dos Passos and Hemingway lost something they cherished. They lost their youth, as Dos Passos makes clear in The Best Times, when from a distance of three decades he hints at their reasons to quarrel. They also lost Europe: the continent would never again have the appeal, the freedom, and the innocence they found there as young men. They lost their shared circle of friends. Not least did they lose the parts of themselves the other inhabited. Dos Passos lost the masculinity and the world of men that Hemingway had provided. He lost the sociability that Hemingway embodied, and the way with the ladies the two had found together and apart. He lost a fellow hypochondriac, the friend who could write and drink and hunt and talk, and the wordfellow with whom he shared routines, frustrations, advice and complaints. He lost his mentor, and the agitator who shared his concern for things Spanish. He lost Key West. He lost most of his talent. He lost his travel companion. He got angrier, taking what Giles Deleuze in "Nomad Thought" calls "trips in intensity," a journey relating both to an older autobiographical self recalling its youth and to a movement in situ (149). He lost, in a sense, himself and his generation.

Hemingway said goodbye to parts of himself that would have lightened his load. Without Dos Passos tugging at his high horse, Hemingway's tendencies towards self-aggrandizement galloped away. Without Dos Passos asking for help, financial and editorial, he lost the generosity that Dos Passos had and Hemingway needed. After the break, Hemingway not only accused Dos Passos of greed and corruption but asked him to pay back his loans. Significantly, Hemingway uses economic metaphors in describing what he considers Dos Passos's betrayal: "Good old friends you know. Knife you in the back for a quarter. Anybody else charge fifty cents" (Baker, Letters, 464). Hemingway's view of Dos Passos's writings also got less generous than in the best times. In a July 1947 letter to William Faulkner from La Finca in Cuba, he concludes that Dos Passos "was a $2^{\text {nd }}$ rate writer on acct. no ear" (Baker, Letters, 623). 
Dos Passos's optimism had fuelled Hemingway throughout their friendship, a source of hope and fun the older Hemingway had to do without. Dos Passos mentions in The Best Times "the Walt Whitman-narodnik optimism about people I've never quite lived down" (87). Hemingway now had to find friends or writers elsewhere to cheer him up, as his letter to Faulkner suggests: "Anyway I am your Bro. if you want one that writes and I'd like us to keep in touch." He then tells Faulkner about the events, primarily his sons' accidents, sicknesses and wounds, that contribute to "Things never been worse than now." "Excuse chickenshit letter," he concludes. "Have much regard for you. Would like to keep on writing [letters]" (Baker, Letters, 624, 625). Hemingway obviously missed a fellow writer to provide a brighter view of his life at mid-century. But in 1947, Dos Passos had other disasters with which to contend. Blinded by a setting sun, he drove his grey Chevrolet roadster into a truck near Wareham, Massachusetts. Katy was decapitated as she slept on his shoulder. Dos Passos lost an eye.

Hemingway lost not just his childhood playmate but also the gentleness that Dos Passos exuded even after the fatal accident that ended his first marriage. With Dos Passos, Hemingway took time off from the demands of masculinity and occasionally allowed himself not to compete, and not to show off. The friendship over, he was left with his own bravado, which he aimed at Dos Passos as well. In his 1947 letter to Faulkner, he links Dos Passos's second-rate writing with his second-rate boxing: "has no left hand, same as ear to writer, and so gets his brains knocked out and this happened to Dos with every book." For good measure, he attacks Dos Passos some more: "Also terrible snob (on acct. of being a bastard) (which I would welcome) and very worried about his negro blood when could have been our best negro writer if would have just been negro as hope we would have" (Baker, Letters, 623-24). The mirror function appears in this attack, as Hemingway in describing Dos Passos equates inferior writing, inferior boxing, and (to him) inferior civil and racial status. Hemingway lost contact with the sensitive, gentle side of himself that Dos Passos represented.

Dos Passos and Hemingway constructed each other as monsters to expel the part of their identity the other occupied. Barbara Johnson argues in "My Monster/My Self" (1982) that the autobiographical impulse originates in the desire to (re)create a being in one's own image. She calls this motivation "the desire for resemblance," in her view "the autobiographical desire par excellence" (3). But the autobiographer might discover a monster in the process of writing life history, and, like Victor Frankenstein in Mary 
Shelley's novel, deny any resemblance to the creating self. Dos Passos and Hemingway solved this problem of genre by projecting onto the other the monstrosities they chose not to face. In Chosen Country (1951), Dos Passos portrays his old friend as the writer George Elbert Warner, a selfish and destructive figure that infuriated Hemingway. He in turn created a monstrous Dos Passos when writing to a friend that his household "supported a pack of fierce dogs and cats trained to attack one-eyed Portuguese bastards who wrote lies about their friends" (Baker, Life, 495). Donald Pizer notes in his analysis of the two writers' fictional aggression that "there is a temptation to think of the four accounts as having a punch-counter-punch sequence: To Have and Have Not (1937) followed by Chosen Country (1951) followed by A Moveable Feast (1964, written 1957-60) followed by Century's Ebb (1975, written 1960-70)" (Pizer, "Hemingway - Dos Passos," 116-117). Hemingway surely felt punched enough to see Dos Passos and his books as monstrously unpleasant. "The [Reginald] Marsh things in Dos's books were absolutely atrocious," he writes to Max Perkins from La Finca in 1947. "I am not surprized Dos's didn't sell. None of the separate parts did. All of ours did and still do in some form" (Baker, Letters, 617). This final comparison suggests both Hemingway's fiercely competitive streak and the tendency in this relationship to study the other, only to find oneself. After they parted, each writer would hold up a mirror to examine the man he had become outside the other's influence. And just behind the mirror, the other lurked monstrously, ready to pounce.

So did the world. After the war to end wars, members of the Lost Generation had been immersed in contingency and chaos. They constructed order and meaning only through their own agency, with individual love and friendship so important to their identity, their work, and their lives that some affection remained between the two writers. "Well Hem you old salamander," Dos Passos writes from Palisades, NY, in June 1949. He jokes about his farming and lets his old creditor know that it is "much more fun than other ways of running into debt." He has kind words for Mary, the fourth Mrs. Hemingway, and ends with a postscript in the masculine language of his old friend: "Damn nice to get a letter: write again" (Ludington, $14^{\text {th }}$ Chronicle, 588-89). In October, 1951, Dos Passos sent condolences upon Pauline's death and obviously tries to comfort Hemingway (or alleviate his guilt) by stressing that she died "suddenly and quickly, the way we would all like to die." He fondly remembers the Pfeiffer sisters and again tries to mend old cuts: "October's a month when everything seems far away and 
long ago" (Ludington, $14^{\text {th }}$ Chronicle, 597). Hemingway felt less conciliatory but did congratulate Dos Passos on his marriage to Elizabeth Hamlin Holdridge in 1949. He even teased Dos Passos a bit, and bonded with him about new wives: "I am not trading Miss Mary in on any new models of any kind. But still, a new wife is a good thing for any old Portuguese to have" (Baker, Letters, 676). One year later, Hemingway fumed - with good reason-over Chosen Country, in which Dos Passos not only trespassed upon Northern Michigan terrain but also opened Hemingway's wounds about Katy: "he marries Katey and kills her dead finally when he drives into the back of a truck. The windshield cuts her throat and Honest John loses an eye" (Baker, Letters, 75).

Both John Dos Passos and Ernest Hemingway survived their Great War experiences and wrote about them in the fiction that brought them fame. They bonded over war and ink and became fellow travellers and wordslingers in the post-war years until their friendship ended over Spanish Civil War politics in 1937. They both got wounded in WWI-young Hemingway in his legs, Dos Passos more intangibly. They lost their trust in American dreams and ideals and devoted their careers to creating truthful experiences on paper, to clean up the language that slimy-mouthed power brokers had destroyed with fake and hollow rhetoric. Their friendship became one of the compensatory pleasures that helped them get through it all. Dos and Hem were both different and alike, though critics have stressed their contrasting personalities, experiences and stylistic innovations most. When their friendship turned into animosity with the José Robles murder and the unfinished Spanish Earth, Dos Passos and Hemingway changed from being celebrated members of the Lost Generation to being lost. They lost their trust in each other, their professional companionship, even themselves, and ultimately they had to face the monster of modernity alone.

In The Best Times Dos Passos brings back old days in Key West with an anecdote that illustrates the complexities and ambiguities of the two writers' relationship. Dos Passos and Katy arrived "one fine day" and found in their friends' house a "horrible bust" of Hemingway that some sculptor had produced: "We let out a roar of laughter when we first saw it. We couldn't imagine that Ernest could take it seriously." Dos Passos got into the habit of ringing it with his panama hat whenever he came by that winter: "Ernest caught me at it one day, gave me a sour look and took the hat off the bust's head. He was grouchy for the rest of the day." Dos Passos's story captures not only the two writers' differences, their conception of self and other, 
the power relations that remain open to interpretation and discussion, but also the silence that ultimately articulated Dos Passos's attitude to the Old Monster: "Nobody said anything but after that things were never quite so good" (BT 220).

\section{Works Cited}

Baker, Carlos. Ernest Hemingway: A Life Story. New York: Scribner's, 1969.

—, ed. Ernest Hemingway: Selected Letters: 1917-1961. New York: Scribner's, 1981.

Carr, Virginia Spencer. Dos Passos: A Life. Garden City, NY: Doubleday, 1984.

Deleuze, Giles. "Nomad Thought." In: The New Nietzche. Ed. David B. Allison. New York: Dell, 1977.

Dos Passos, John. The Best Times: An Informal Memoir. London: Andre Deutsch, 1968.

_. "Farewell to Europe." Common Sense 6 (July 1937): 9-11.

Eakin, Paul John. How Our Lives Become Stories: Making Selves. Ithaca: Cornell UP, 1999. Johnson, Barbara. "My Monster/My Self." Diacritics 12 (1982): 2-10.

Koch, Stephen. The Breaking Point: Hemingway, Dos Passos, and the Murder of José Robles. New York: Counterpoint, 2005.

Ludington, Townsend, ed. The Fourteenth Chronicle: Letters and Diaries of John Dos Passos. Boston: Gambit, 1973.

—.John Dos Passos: A Twentieth Century Odyssey. New York: E. P. Dutton, 1980.

-. "Spain and the Hemingway-Dos Passos Relationship." American Literature 60.2 (May1988): 270-73.

Moorehead, Caroline. Gellhorn: A Twentieth-Century Life. New York: Henry Holt, 2003.

Pizer, Donald. "The Hemingway-Dos Passos Relationship." Journal of Modern Literature 13.1 (March 1986): 111-28.

- . "The Sexual Geography of Expatriate Paris." Twentieth Century Literature 36.2 (Summer 1990): 173-85.

Reynolds, Michael. Hemingway: The Paris Years. Oxford: Blackwell, 1989.

Shen, Dan and Dejin Xu. "Intratextuality, Extratextuality, Intertextuality: Unreliability in Autobiography versus Fiction." Poetics Today 28.1 (Spring 2007): [43]-87.

Wilson, Edmund, I Thought of Daisy. 1929. New York: Farrar, Straus and Giroux, 1967. 
